Multi-scale foraging decisions made by woodland caribou (Rangifer tarandus caribou) in summer

By

\title{
Eric McNeill
}

A Thesis

presented to

The University of Guelph

\author{
In partial fulfillment of requirements \\ for the degree of \\ Masters of Science \\ In \\ Integrative Biology
}

Guelph, Ontario, Canada

(C) Eric McNeill, May, 2015 


\section{ABSTRACT \\ Multi-scale foraging decisions made by woodland caribou (Rangifer tarandus caribou) in summer}

Eric McNeill

University of Guelph, 2015
Advisor:

Professor J. M. Fryxell

Multi-scale selection patterns can be understood from two perspectives: one that sees coarse scale patterns as the summation of fine scale patterns and the other that sees it as a hierarchy produced from multiple contributory factors. Here I examine caribou selection of foraging locations across three spatiotemporal scales to determine if caribou foraging behavior is hierarchical or scaling-up in nature. Seven adult female caribou were equipped with GPS telemetry radio-collars with high definition video cameras that recorded foraging choices throughout the summer. Fine-scale data from videos were used to estimate food plant selection across feeding stations, food patches, and forest stands. Caribou exhibited resource selection at all spatial scales, with some patterns consistent across some scales. The resource use patterns suggested selection at one or two scales, but not at all scales. My study suggests that even at very fine scales, caribou selection for foraging locations is hierarchical. 


\section{ACKNOWLEDGEMENTS}

This work was possible because of a massive collaborate effort between researchers at the University of Guelph, Wildlife Research and Development Division and the Center for Northern Forest Ecosystem Research of the Ontario Ministry of Natural Resources, and the University of Trent. I owe many thanks to a great many people.

I would first like to thank my advisor John Fryxell for all the support and guidance he has provided me throughout this endeavour. I was given the freedom to make my own mistakes and consequently better myself in the process knowing that I had his support if the situation became grim. For that I am very grateful. I would like to thank my committee members, Ian Thompson and Rob McLaughlin, for their invaluable advice. My current and past lab members (Derek Morningstar, Madeleine McGreer, Andrew Kittle, Luke Vander Vennen, and especially Garrett Street) were very helpful in the development of this work. My ability to do the field component of this work was greatly enhanced by the pleasure of working with Erin Mallon, Marco Raponi, and Phil Wiebe. To Phil Wiebe, in particular, I owe many thanks, particularly for showing me the ways of working in the Ontario boreal forest. I could not have asked for better field technicians than Becky Vijeou and Graydon McKee. Their dedication and good company did not go unnoticed. A big thank you to all the people of Nakina who made me feel welcome.

I am grateful for personal financial support from Teaching Assistantships from the University of Guelph, and research assistantships from my advisor John Fryxell. Financial support for the wolf-caribou-moose demography project was provided by the Forest Ecosystem Science Co-operative Inc., NSERC CRD program, Canadian Forest Service, the Wildlife Research and 
Development Division and the Center for Northern Forest Ecosystem Research of the Ontario Ministry of Natural Resources.

Finally, I would like to thank my family and friends whose interest in my work motivated me to keep pushing on. 
TABLE OF CONTENTS

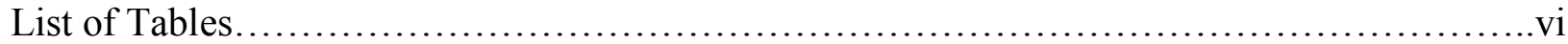

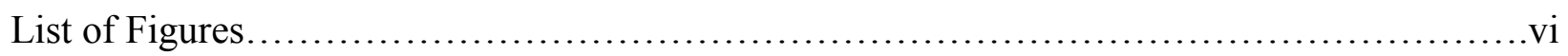

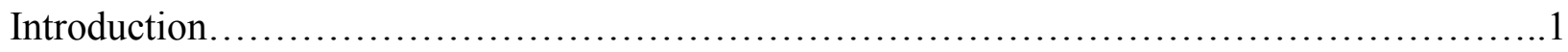

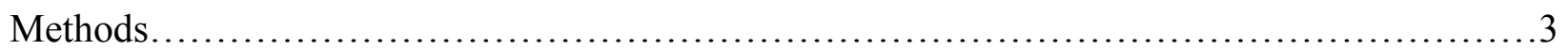

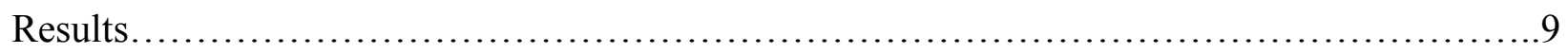

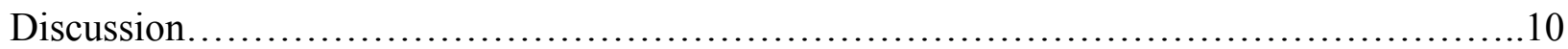

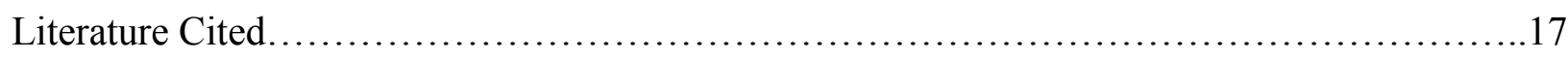

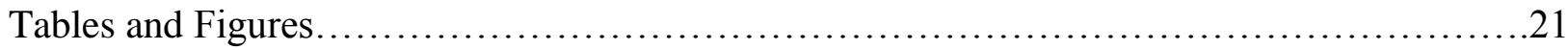




\section{LIST OF TABLES}

Table 1: Individual caribou collar data details.

Table 2: V/W-type amalgamations in to patch classes.

Table 3: Total number of bites by food item.

Table 4: Plant scale resource selection function estimates.

Table 5: Vegetation type scale resource selection function estimates.

Table 6: Forest stand scale resource selection function estimates.

Table 7: Summary of food items selected with respect to scale of observation.

\section{LIST OF FIGURES}

Figure 1: Percentage of total number of bites by food item.

Figure 2: Proportion used and available patch classes.

Figure 3: Proportion used and available stand types.

Figure 4: Percent cover of food items by stand type.

Figure 5: Percent cover of food items by patch class.

Figure 6: Proportion of patch classes composing stand types. 


\section{INTRODUCTION}

The importance of scale in the study of any ecological phenomena is fundamental to our understanding of the mechanisms that produce the patterns we observe. Ecologists have become increasingly aware that patterns observed at one scale are not necessarily observed at others. For example, Johnson et al. (2001) studied caribou woodland habitat selection at three spatiotemporal scales. At the smallest scale, the scale of the feeding site, they found that caribou selection was influenced by the availability of certain lichen species, however, at a larger spatial scale, the scale of the patch, lichen availability was not relevant. Anderson et al. (2005) studied elk resource selection at two scales. Elk selection for home ranges was explained largely by predation, but selection for resources within their home ranges was explained by forage availability. Senft et al. (1987) studied cattle foraging behavior and found that grazing across the landscape was random but cattle were selective at the level of local plant communities. These studies suggest that resource selection patterns can be dependent on the scale of observation and thus warrant the need for multi-scale studies. When we observe differences in selection patterns across scales a framework is required to interpret the scale-specific importance of selected resources.

One possible mechanism for variation in selectivity across scales is the hierarchal hypothesis. Patterns like those reported by Johnson et al. (2001) are often interpreted as resulting from scale-specific processes shaping animal behavior (Levin 1992, Rettie and Messier 2000). Rettie and Messier (2000) suggested that caribou selection for forage is only observed at fine scales because selection against predator risk has much stronger effect on caribou fitness compared to nutritional requirements. Rettie and Messier (2000) hypothesized that the factors influencing animal decisions about space use at coarse spatial scales are more important to individual fitness than those only seen at fine scales, resulting in a hierarchical selection pattern. In 
general, the most important limiting resource should be selected at coarser scales to reduce its limiting effect on fitness.

A plausible alternate hypothesis is the scaling-up hypothesis where coarse scale patterns merely reflect the summation of fine scale patterns (Levin 1992). In this view, coarse-scale patterns are necessarily a collection of finer-scale patterns. If one wants to gain insight into the habitat characteristics necessary for survival, the scaling-up hypothesis suggests it is critical to understand the underlying causes of variation in resource selection patterns at the fine spatiotemporal scales (Manly et al. 2002, Mayor et al. 2009).

Ontario's woodland caribou (Rangifer tarandus caribou) are designated by COSEWIC as Threatened, a status retained since 2000. Research suggests their decline can largely be attributed to two factors: (1) extensive habitat removal caused by human developments including logging, and (2) apparent competition with moose (Alces alces) contributing to increased predation by grey wolves (Canis lupus) and black bears (Rettie and Messier 1998, Wittmer et al. 2005, Festa-Bianchet et al. 2011, Pinard et al. 2012). These two factors are also closely linked.

Thompson et al. (2015) conducted a comprehensive study on woodland caribou diet composition and forage selection based on food plant availability averaged over a $23,000 \mathrm{~km}^{2}$ study site near Nakina, Ontario. My follow-up study in the same site differs by focusing on different spatial scales of food selection and by measuring resource availability strictly within the individual forest stands used by our study animals. Owen-Smith et al. (2010) described several spatiotemporal scales biologically relevant to large mammalian herbivore foraging behavior, three of which coincide with the scales in my study. I estimated resource selection functions (RSF) for caribou habitat and diet at three spatial scales: the foraging station, food patch, and foraging area 
spatial scales match, respectively, with what I refer to as the scale of the plant, vegetation type, and forest stand.

My first objective was to test whether caribou select foraging locations at the scale of the plant, vegetation type, and forest stand. My second objective was to compare the patterns of selection among all three scales in relation to the two paradigms of understanding multi-scale patterns, scaling-up or hierarchical. Consistency in selection patterns across the three scales provides evidence for the scaling-up hypothesis. Conversely, selection patterns that change depending on the scale of observation provide evidence for the hierarchical hypothesis.

Observing the foraging behavior of large mammals in the wild is often extremely difficult due to inaccessibility and reluctance by wild animals to be accompanied by humans. My study is unique in that I was able to observe fine-scale foraging behavior using remote global positioning system (GPS) telemetry radio collars equipped with cameras (Thompson et al. 2012, Newmaster et al. 2013, Thompson et al. 2015). Behavioral data from video collars and field measurements were integrated to perform a comprehensive multi-scale analysis on caribou resource selection for foraging locations.

\section{MATERIALS AND METHODS}

\section{Field data}

The $23,000 \mathrm{~km}^{2}$ study area was located in the boreal shield ecotone north of Geraldton, Ontario. The town of Nakina (approximate population of 500) is located in the southeastern portion of the study area. However, some degree of anthropogenic disturbance is present across

much of the study area due to past and ongoing commercial timber harvest, roads, power lines, rail access, and some commercial lodges which have created a mosaic of forest stands in various seral 
stages and some corridors. Common tree species include black spruce (Picea mariana), jack pine (Pinus banksiana), white spruce (Picea glauca), balsam fir (Abies balsamea), white birch (Betula papyrifera), trembling aspen (Populus tremuloides), tamarack (Larix laricina) and white cedar (Thuja occidentalis).

All sampling was conducted in the summer. Spring-summer transition was marked by green leaf emergence on indicator shrubs and forbs (e.g. Alnus rugosa and Cornus canadensis) and summer-fall transition was marked by leaf senescence whereby the majority of leaves had changed color. According to these arbitrary criteria, June 16 was chosen as the start of the summer for 2011 and 2013 and June 5 for 2012. September 9 was the end of summer for all years.

Caribou habitat use was obtained from GPS telemetry radio/video collars. Collars were equipped with cameras that were programmed to record 10-second video segments on a duty-cycle. The cycle range, video frequency, GPS frequency and collar duration differed among individual caribou (Table 1). Cameras were oriented on the underside of the caribou's neck, facing forward such that the field of view captured what was in front of the caribou. The primary and secondary behaviors of caribou (based on time allocated to behavior per video) were assessed. Videos pertinent to this study had feeding as either the primary or secondary behavior. Cameras also gave a clear view of caribou jaw movement so that I could readily observe what each caribou consumed (in most cases to genus) and how many bites of a food item were taken. I defined a bite as a jaw movement during consumption (Thompson et al. 2015).

I classified the landscape in my study area using the Ontario Far North Land Cover (FNLC) (OMNR 2013) merged with an earlier Ontario Land Cover map (Spectranalysis Inc. 2004) for areas south of $\sim 50^{\circ} \mathrm{N}$ latitude. The FNLC database describes 25 land cover classes with an additional two classes for areas with unknown features (e.g. clouded areas). 
Because GPS locations were mostly acquired asynchronously with video recordings, the exact location for all videos could not always be determined. This challenge was overcome by relating GPS and video data by the time of recording common to both data streams. Forest stands that contained two sequential GPS locations that encompassed at least one feeding video were defined as foraging areas and were deemed suitable locations for measuring plant species availability at a finer scale. Feeding videos that did not meet these criteria were discarded. These strict criteria were set in place to ensure that sampling was restricted to stands with a high probability of having been used for feeding by caribou. 101 stands in total met these criteria.

I sampled plant species availability in stands identified as foraging areas. I tried to achieve a representative distribution of used stand classes for each caribou. However, due to logistical constraints on accessibility and timing, some candidate stands could not be sampled. This led to some caribou and some stand types being sampled more than others and some forest stand types being rarely visited, such as the sparse treed class, which was seldom used for foraging and was generally inaccessible by either road or water in our remote landscape. I sampled 31 stands containing a total of 383 feeding videos (Table 1).

Forage species availability was estimated by measuring percent cover in 1 x $1 \mathrm{~m}$ quadrats placed systematically every $25 \mathrm{~m}$ along straight lines beginning at a randomly selected point in the stand. The distance between quadrat locations was a balance between having large enough spacing to account for any within-stand spatial gradients that may have been present and having small enough spacing to allow reasonable levels of statistical replication. I considered that $25 \mathrm{~m}$ spacing represented a reasonable trade-off between these criteria. The initial quadrat placement was drawn at random. Any time that a subsequent quadrat location would have taken me outside of the stand as defined in our GIS database, the direction was changed to be orthogonal to the initial trajectory. 
This randomization process was repeated until availability had been sampled in 20 quadrats, with the exception of one stand (marsh) where only 12 measurements were possible because of limited size and elongated shape of the area. Estimation of percentage cover in quadrats was based on Mallon's (2014) methodology. Percentage cover was measured in increments of $0.01 \%$ for those species whose cover fell below $0.1 \%, 0.1 \%$ for those falling between $0.1 \%$ and $1 \%$, and $1 \%$ for those species whose cover exceeded $1 \%$. Because cover data were binned, the sum of all cover estimates for a given quadrat can exceed $100 \%$. Some species were identified to genus, because they are differentiable only on the basis of inconspicuous traits that are difficult if not impossible to assess in the field. For example, all peat mosses were pooled as Sphagnum spp.

In addition to measuring percentage cover, the vegetation type (v-type) at every quadrat was assessed. A v-type is a small scale $(10 \mathrm{x} 10 \mathrm{~m})$ land cover class in the Northwestern Ontario Forest Ecosystem Classification (NWO FEC) system. NWO FEC describes 38 v-types that range from dry, hardwood to wet, coniferous swamp. Over-story species, ground vegetation, moisture, and soil characteristics are the main features used to define v-types. NWO FEC does not include an in-depth classification scheme for very saturated/flooded areas so the NWO Wetland Ecosystem Classification (WEC) system was used in conjunction when necessary. NWO WEC describes 36 wetland communities (w-types) that range from submerged marshes to coniferous swamps that broadly overlap with the wettest v-types described by NWO FEC.

V/W-types that appeared in sampling were merged into 12 habitat classes (Table 2). Merging was based on the difficulty associated with differentiating among some v/w-types from video data. For example, a key characteristic used to differentiate V35 from V36 is the amount of Alnus rugosa cover. Because A. rugosa can be present in both v-types and estimating percent cover 
from video is difficult, these classes were merged. Merged classes were closely located in the FEC ordination of v/w-types (Harris et al. 1996, Sims et al. 1997)

\section{$R S F$ models}

To identify the factors influencing selection of foraging locations at three spatial-temporal scales, I used resource selection functions (RSF) following a used available structure (Manly et al. 2002):

$$
\mathrm{w}(\mathrm{x})=\exp \left(\beta_{0}+\beta_{1} \mathrm{x}_{1}+\beta_{2} \mathrm{x}_{2}+\ldots \beta_{\mathrm{k}} \mathrm{x}_{\mathrm{k}}+\gamma_{0 \mathrm{j}}+\delta_{0 \mathrm{j}}\right)
$$

Following the normal procedure in the RSF literature (Manly et al. 2002), I used mixed effect logistic regression to estimate parameters for this log-linear model, where $\mathrm{x}_{\mathrm{i}}$ is a predictor variable and $\beta_{\mathrm{i}}$ its corresponding coefficient. I included animal identity and individual forest stand identification as random effects on the intercept $\left(\gamma_{0 \mathrm{j}}\right.$ and $\delta_{0 \mathrm{j}}$ respectively) to address unbalanced sample sizes and spatial correlation for the plant and vegetation type RSFs but not the stand RSF (Gillies et al. 2006). Used units are resource units encountered by caribou that they decided to feed in and available units are resource units that caribou could have potentially encountered (Lele et al. 2013). Selection refers to positive RSF coefficients and avoidance refers to negative coefficients.

In the plant RSF, the used distribution was represented by the presence or absence of food items in the $1 \times 1 \mathrm{~m}$ area captured by caribou feeding videos. 368 feeding videos comprise this used distribution. This is less than the 383 feeding videos possible for two reasons. First, in some videos where caribou fed on arboreal lichen, I was not able to properly determine what other food items were available on the ground. Second, in a small number of videos, an individual caribou fed 
at two locations within the span of $10 \mathrm{sec}$. In these rare instances I treated each location separately when assessing presence of food items. A reference category was not required for the plant species RSF model because perfect collinearity was not an issue as a result of multiple species occurrences within many 1 x 1 m quadrats. The available distribution stems from 612 randomly sampled 1 x 1 m quadrats for the presence or absence of important food items. Some sampled stands were fed in by two caribou and thus the availability in those stands applies to both animals. Because of this the available distribution is represented by 692 randomly sampled 1 x 1 m locations.

Clearly, some plant species are more important to caribou diets than others (Newmaster et al. 2013, Thompson et al. 2015). Because my study is largely about understanding changes in preference across spatial scales, some rare plant types were not included in my analysis. I arbitrarily restricted my predictor variables to only those species that comprised at least $1 \%$ of the total amount of bites taken by all caribou (Figure 1). This was helpful in obtaining convergence in the non-linear parameter estimation procedure. Species not included as predictor variables summed to $<7 \%$ of the total amount of bites (Table 3). Arboreal lichen and fungi were not included as predictor variables even though they composed $>1 \%$ of the bites taken. Patches of arboreal lichen are present virtually everywhere in my study area, but the camera was rarely in a position to see arboreal lichen on the neighboring trees because study animals did not look skywards very frequently. Fungi were also particularly difficult to see in videos. Fungi were present in small quantities $\left(<5 \mathrm{~cm}^{2}\right.$ in a $1 \times 1 \mathrm{~m}$ quadrat), and obscured by ground cover. Because of biases in the estimation of arboreal lichen and fungal availability from the video data, selection ratios for these species at the scale of the plant would be pointless.

In the vegetation type RSF, the used distribution was represented by the v/w-type groups from the locations determined from caribou feeding videos (383 locations). The available 
distribution was represented by 692 randomly sampled v/w-types (the same locations as the plant RSF) across 31 stands that caribou in which caribou fed. I set the reference category to be the v/w-type that had the smallest difference between the proportion it was used and the proportion it was available that also had relatively high sample size. I used this criterion for ease of interpretation of all other coefficients in the model. Lowland/bog was set as the reference category for this RSF. One covariate, the deciduous patch class, was never used by caribou in our sample and was discarded to allow convergence in the mixed effect modeling procedure.

In the stand type RSF, the used distribution was represented by the number of videos in a stand class. For example, 103 feeding videos were in coniferous treed stands, therefore 103 out of 383 locations in the used distribution corresponded to the coniferous treed class. The available distribution was represented by 3830 randomly sampled locations (i.e., 10 available: 1 used) distributed within the summer home ranges of each caribou, based on the $100 \%$ minimum convex polygons developed by using the method of McGreer et al. (2015). FNLC classes 1 and 2, clear open water and turbid water, respectively, were excluded from the available distribution. I did not include these classes on the basis that my method for sampling species availability was not developed to adequately cope with the unique nature of aquatic vegetation. Following the same reasoning as the vegetation type RSF, treed bog was set as the reference category for this RSF. I used the statistical program R (version 3.1.3, R core team 2015) for all analyses.

\section{RESULTS}

Caribou showed selection at all spatiotemporal scales. At the scale of the plant, in order from strongest to weakest, caribou selected for Clintonia borealis and Cladina (Table 4). In order 
from strongest to weakest, caribou avoided Maianthemum trifolium and Maianthemum canadense. Diervilla lonicera, graminoids, Aralia nudicaulis, Equisetum, and Menyanthes trifoliata were all used proportionate to availability.

At the scale of the vegetation type used for feeding, caribou selected solely for the upland open understory and class (Figure 2, Table 5). In order from strongest to weakest, caribou avoided rich fen, marsh, balsam fir mix, black spruce/jack pine mix, balsam fir coniferous, and poor fen patch classes. Caribou avoided and never fed in the deciduous patch class. All other patch classes were used in proportion to their availability.

At the scale of the stand, caribou selected most strongly for the freshwater marsh stand type, followed by treed fen, treed disturbance, and mixed types (Figure 3, Table 6). Caribou avoided sparse disturbance and coniferous swamp stand types. These are differentiated from the avoidance of thicket swamp, open fen, open bog, and community/infrastructure that were never used. As mentioned previously, due to field constraints I was unable to sample the sparse treed stand type.

Plant availabilities differed substantially between patch classes and stand types (Figures 4 and 5) as well as the proportion of patch classes composing stand types (Figure 6).

\section{DISCUSSION}

Caribou are often considered to be obligate lichen foragers. While this is true in winter, caribou diets are broader in the summer, although a large proportion of even the summer diet is lichens (Thompson et al. 2015). When females are caring for calves, the reproductive demand for protein $(\mathrm{N})$ in milk production is high (Parker 1990). To meet this elevated demand, caribou would have to include food items other than lichen (Adamczewski et al. 1987). During the calf rearing 
period, woodland caribou experience the greatest magnitude of forage availability and take advantage of that abundance by expanding their diet to include grasses, fern-allies, and forbs (Thompson et al. 2015).

The plant RSF showed that $C$. borealis is an important diet item in addition to Cladina, which may influence caribou foraging decisions at the scale of the plant. The plant RSF also showed that both species in the Maianthemum genus were avoided. M. canadense and M. trifolium constitute approximately 3\% and $9 \%$ of caribou diet respectively, thus it is unlikely that these species negatively affect caribou, which is often an interpretation when a variable is avoided (Johnson 1980). M. canadense was common in well-drained higher elevation habitats whereas $M$. trifolium was common in poorly-drained low elevation habitats, however, both species can also occur in smaller quantities in other terrain types. It is likely that the negative coefficient of selection for the Maianthemum species is due in part to their relatively large availability and in part that they can co-occur with more preferred food items (i.e. Cladina) and can be regarded as incidental forage.

The hypothesis that fine-scale decisions scale up to create coarser patterns of preference predicts that caribou should select for patch classes with relatively high cover of Cladina. The positive selection by caribou for the upland understory class supports this prediction (Table 7). As its name suggests, the open understory class possesses minimal shrub cover, with the ground layer being composed primarily of feather moss, litter, or barren rock. This class often contains very high quantities of Cladina (especially V30 where lichen cover $\geq 20 \%$ ). The other food items making up the caribou diet were sometimes present at very low quantities in this patch class, thus it is unlikely that caribou were selecting upland open understory for anything but Cladina. 
The hypothesis that fine-scale decisions scale up to create coarser patterns of preference similarly predicts that caribou should select for the balsam fir coniferous or deciduous classes where $C$. borealis cover is relatively high. Both of these classes were avoided. Hence, there is little evidence of scaling-up patterns in patches with respect to C. borealis. Despite its strong dietary selection coefficient, $C$. borealis does not appear to be an important indicator of preferential use at the patch scale. Similarly, there was no clear evidence of a scaling-up effect for M. trifoliata, A. nudicaulis, D. lonicera, graminoids, and M. trifolium. Patch classes associated with relatively high availabilities of these food items were avoided except for $M$. trifolium which was used in proportion to its availability at the patch scale. There was, however, support for the scaling-up hypothesis with regards to Equisetum and M. canadense. Patch classes containing relatively high availabilities of Equisetum were both used proportionately to availability and avoided. Both classes containing the highest availabilities of $M$. canadense were avoided.

Interpretation of selection patterns at the stand scale with regards to the availability of the different food items must be approached differently than that of the patch scale because of how availabilities were measured. Availability in stands is represented by only those that were used by caribou among all available stands, thus biasing estimates to the fraction of stands in which caribou had already made the decision to forage. The conclusions any observer of resource selection makes are critically dependent on what is deemed available to the animal (Johnson 1980). In the stand scale discussion that follows, I acknowledge that my estimates of forage availability and patch composition are drawn solely from stands in the used distribution but consider them nonetheless useful when assessing how caribou can improve the amount of resources they experience. 
Caribou exhibited selection for a diverse set of stand types ranging from wetlands to uplands. The relative abundance of forage items in stands selected indicate that stand selection was influenced to some degree by all forage items except Cladina and A. nudiaulis. Cladina cover was relatively uniform across all stand types except in freshwater marshes and deciduous stand types where it is rare. A. nudicaulis is present in the selected mixed stand type but cover is equal to that in the avoided coniferous swamp class.

Foraging decisions made by caribou are undoubtedly influenced by several factors besides forage abundance. Factors in addition to forage availability that are hypothesized to influence caribou habitat selection include risk of predation (Schaefer et al. 1999), insect harassment (Mörschel and Klein. 1997), and thermal regulation (van Beest et al. 2012). A combination of these factors in addition to forage abundance may explain some of the patterns that I observed (Belovksy, 1991). For example, avoidance of rich fens was also reported by Hillis et al. (1998) in Northwestern Ontario. Their analysis was conducted at a broader scale than the vegetation type RSF (25 x 25m pixel resolution) where they found that the shrub-rich land cover class was avoided relative to other lowland classifications that were used heavily (i.e.,treed bogs). Hillis et al. (1998) concluded that caribou avoided the shrub-rich habitats because they are favored by moose. What was particularly interesting in my study was the strong avoidance of rich fen and its contrast with the comparatively weak avoidance of poor fen. The rich fen class had forage availabilities that were little different from poor fen with the exception of $M$. trifoliata, which was more abundant in poor fens. This suggests that caribou decisions to use poor fens more strongly than rich fens stems from the higher availability of $M$. trifoliata in poor fens. The availability of $M$. trifoliata may explain why poor fens are used more strongly than rich fens, and this criterion may extend to the other avoided classes. This scenario suggests that $M$. trifoliata may play an important role in 
shaping caribou choice of vegetation types, at least within some forest stand types, but had little influence at the finest scale examined: at the level of the individual plant. Caribou avoidance of rich fens in my study may thus result from a combination of predator avoidance and stronger use for the more favorable poor fen with greater M. trifoliata cover.

Caribou selection for poorly-drained open areas has been frequently observed (Lantin et al. 2003, Briand et al. 2009, Latham et al. 2011). This is consistent with the anti-predator hypothesis, where increased visibility may be a defining characteristic of risky habitats (Brown 1999, Hebblewhite et al. 2005, Dussault et al. 2012). However, this assertion is somewhat at odds with my observation that caribou also selected for the mixed stand type. Mixed stands generally contain an abundance of broad leaf forage and are thus suitable habitat for moose. Since wolves, the primary predator of caribou adults, preferentially occur in moose habitat (Kittle et al. 2015), caribou face a trade-off between forage availability and predation risk in the summer (McGreer et al. 2015). Recent studies of movement and caribou diet choice in relation to nutritional parameters suggest that bottom up limitations to caribou fitness are of greater importance than previously thought (Newmaster et al. 2013, Mallon 2014, Avgar et al. 2015, McGreer et al. 2015, Thompson et al. 2015). It may be too simplistic to think of habitats as solely contributing to risk avoidance or access to food resources, caribou may select habitats to maintain an appropriate mixture of each benefit. By this reasoning, caribou selection for mixed stand types may be out of necessity to improve access to energetically-valuable broad leaf forage.

Thompson et al.'s (2015) study on caribou diet composition was conducted in the same study area and included five of the caribou used in my analyses, however there were differences in some of the selection patterns observed and the diet composition estimates. These differences can be attributed to two factors: the addition of three caribou in our analysis and, more importantly, 
different definitions of forage availability. Johnson (1980) demonstrated that the operating definition of available resources has a strong influence on resource selection estimates. The proportion of resources available is obviously dependent on the available area which will correspondingly influence selection estimates. In my study I restricted the availability measurements to forest stands actually visited by caribou and in which there was a high probability of feeding, whereas Thompson et al. (2015) sampled plant availability across the entire study area. Local availability estimates coming from forest stands in which caribou have fed are more appropriate for measuring selection at fine scales as compared to forest stands kilometers away. Two of the additional caribou from the Nakina study area included in only my study, CAU310 (2013) and CAU312, constituted approximately $22 \%$ and $26 \%$ of the feeding videos included in my analyses and were likely responsible for the differences in diet composition between studies.

An important question that remains is how to interpret the scenario where one foraging item is selected only at the coarsest scale, whereas another is selected at the coarsest as well as finer scales. Under the hierarchical habitat selection hypothesis, one would conclude that neither foraging item is more limiting than the other because the animal has selected both resources at the coarse scale, but this interpretation is devoid of selection observed at the finer scales. Caribou continue to respond to the availability of one foraging item beyond the coarsest scale, for example, selection for Cladina at both the plant and patch scales, and this should influence how we interpret the relative importance of each resource. It seems elementary to conclude that the foraging item under selection at all scales is of greater importance to caribou fitness relative to the foraging item that is selected only at the coarsest scale but not the finer scale. However, if selection at the coarsest scale was successful to the degree that the availability at finer scales was saturated with the target resource, we should not expect selection to be strong or perhaps even observe selection 
at all at fine scales (McGreer et al. 2015). If we accept this reasoning, then foraging items not selected at finer scales may indeed have greater impact on caribou fitness. If nothing else, the variation in resource selection observed across different spatial scales warrants further development of an appropriate theoretical framework regarding the relationship between critical resources and scale-dependent selection.

My study suggested that patterns of resource selection by woodland caribou drawn at one scale do not necessarily hold true at other spatial scales. Selection patterns for some food items at the finest scale were also observed at the coarser scales, but not for all. Most food items, such as $M$. trifolium, exhibited little evidence of scaling-up patterns in patches. Cladina and M. canadense were the only food items to be selected and avoided, respectively, at the two finest scales. No food items exhibited consistent selection patterns across all three scales under observation. Hence resource selection for forage is scale-dependent. I accordingly conclude that the evidence from my study is most consistent with the interpretation that caribou select foraging locations in a hierarchical fashion. 


\section{LITERATURE CITED}

Adamczewski, J. Z., Gates, C. C., Soutar, B. M., and Hudson, R. J. (1988). Limiting effects of snow on seasonal habitat use and diets of caribou (Rangifer tarandus groenlandicus) on Coats Island, Northwest Territories, Canada.Canadian Journal of Zoology, 66:1986-1996.

Anderson, D. P., Turner, M. G., Forester, J. D., Zhu, J., Boyce, M. S., Beyer, H., and Stowell, L. (2005). Scale-dependent summer resource selection by reintroduced elk in Wisconsin, USA. Journal of Wildlife Management, 69:298-310.

Avgar, T., Baker, J. A., Brown, G. S., Hagens, J. S., Kittle, A. M., Mallon, E. E., McGreer, M. T., Mosser, A., Newmaster, S. G., Patterson, B. R., Reid, D. E., Rodgers, A. R., Shuter, J., Street, G. M., Thompson, I., Turetsky, M. J., Wiebe, P. A., and Fryxell, J. M. (2015). Space-use behaviour of woodland caribou based on a cognitive movement model. Journal of Animal Ecology (in press).

Belovsky, G. E. (1991). Insights for caribou/reindeer management using optimal foraging theory. Rangifer, 11:7-23.

Briand, Y., Ouellet, J. P., Dussault, C., and St-Laurent, M. H. (2009). Fine-scale habitat selection by female forest-dwelling caribou in managed boreal forest: Empirical evidence of a seasonal shift between foraging opportunities and antipredator strategies. Ecoscience, 16:330-340.

Brown, J. S. (1999). Vigilance, patch use and habitat selection: foraging under predation risk. Evolutionary Ecology Research, 1:49-71.

Dussault, C., Pinard, V., Ouellet, J. P., Courtois, R., and Fortin, D. (2012). Avoidance of roads and selection for recent cutovers by threatened caribou: fitness-rewarding or maladaptive behaviour? Proceedings of the Royal Society B: Biological Sciences, 279:4481- 4488.

Festa-Bianchet, M., Ray, J. C., Boutin, S., Côté, S. D., and Gunn, A. (2011). Conservation of caribou (Rangifer tarandus) in Canada: an uncertain future. Canadian Journal of Zoology, 89:419-434.

Gillies, C. S., Hebblewhite, M., Nielsen, S.E., Krawchuk, M. A., Aldridge, C. L., Frair, J. L., Saher, D. J., Stevens, C. E., and Jerde, C. L. (2006). Application of random effects to the study of resource selection by animals. Journal of Animal Ecology, 75:887-898. 
Harris, A.G., McMurray, S.C., Uhlig, P.W.C., Jeglum, J.K., Foster, R.F., and Racey, G.D. (1996). Field guide to the wetland ecosystem classification for northwestern Ontario. Queen's Printer for Ontario, Ontario.

Hebblewhite, M., Merrill, E. H., and McDonald, T. L. (2005). Spatial decomposition of predation risk using resource selection functions: an example in a wolf-elk predator-prey system. Oikos, 111:101-111.

Hillis, T. L., Mallory, F. F., Dalton, W. J., and Smiegielski, J. (1998). Preliminary analysis of habitat utilization by woodland caribou in northwestern Ontario using satellite telemetry. Rangifer, 18:195-202.

Johnson, C. J., Parker, K. L., and Heard, D. C. (2001). Foraging across a variable landscape: behavioral decisions made by woodland caribou at multiple spatial scales. Oecologia, 127:590-602.

Johnson, D. H. (1980). The comparison of usage and availability measurements for evaluating resource preference.Ecology, 61:65-71.

Lantin, É., Drapeau, P., Paré, M., and Bergeron, Y. (2003). Preliminary assessment of habitat characteristics of woodland caribou calving areas in the Claybelt region of Québec and Ontario, Canada. Rangifer, 23:247-254.

Latham, A. D. M., Latham, M. C., and Boyce, M. S. (2011). Habitat selection and spatial relationships of black bears (Ursus americanus) with woodland caribou (Rangifer tarandus caribou) in northeastern Alberta. Canadian Journal of Zoology, 89:267-277.

Lele, S. R., Merrill, E. H., Keim, J., and Boyce, M. S. (2013). Selection, use, choice and occupancy: clarifying concepts in resource selection studies. Journal of animal ecology, 82:1183-1191.

Levin, S. A. (1992). The problem of pattern and scale in ecology: the Robert H. MacArthur award lecture. Ecology, 73:1943-1967.

Mallon, E. E. (2014). Effects of disturbance and landscape position on vegetation structure and productivity in Ontario boreal forests: implications for woodland caribou (Rangifer tarandus caribou) forage. MSc Thesis, University of Guelph. 
Manly, B. F. J., McDonald, L. L., Thomas, D. L., McDonald, T. L., and Erickson, W. P. (2002). Resource selection by animals: statistical analysis and design for field studies. Second Edition. Kluwer Academic, Dordrecht.

Mayor, S. J., Schneider, D. C., Schaefer, J. A., and Mahoney, S. P. (2009). Habitat selection at multiple scales. Ecoscience, 16:238-247.

McGreer, M. T., Mallon, E. E., Vander Vennen, P.A. Wiebe, Baker, J. A., Brown, G. S., Avgar, T., Hagens, J., Kittle, A. M., Mosser, A., Street, G. M., Reid, D. E. B., Rodgers, A. R., Shuter, J., Thompson, I. D., Turetsky, M. J., Newmaster, S. G., Patterson, B., and Fryxell, J. M. (2015). Selection for forage and avoidance of risk by woodland caribou (Rangifer tarandus caribou) at coarse and local scales. Ecosphere (in press).

Mörschel, F. M., and Klein, D. R. (1997).Effects of weather and parasitic insects on behavior and group dynamics of caribou of the Delta Herd, Alaska. Canadian Journal of Zoology, 75:1659-1670.

Newmaster, S. G., Thompson, I. D., Steeves, R. A., Rodgers, A. R., Fazekas, A. J., Maloles, J. R., McMullin, R.T., and Fryxell, J. M. (2013). Examination of two new technologies to assess the diet of woodland caribou: video recorders attached to collars and DNA barcoding. Canadian Journal of Forest Research, 43:897-900.

Owen-Smith, N., Fryxell, J. M., and Merrill, E. H. (2010). Foraging theory upscaled: the behavioural ecology of herbivore movement. Philosophical Transactions of the Royal Society B: Biological Sciences, 365:2267-2278.

Parker, K. L., White, R. G., Gillingham, M. P., and Holleman, D. F. (1990). Comparison of energy metabolism in relation to daily activity and milk consumption by caribou and musk neonates. Canadian Journal of Zoology , 68:106-114.

Pinard, V., Dussault, C., Ouellet, J. P., Fortin, D., and Courtois, R. (2012). Calving rate, calf survival rate, and habitat selection of forest-dwelling caribou in a highly managed landscape. The Journal of Wildlife Management, 76:189-199.

R Core Team (2013). R: A language and environment for statistical computing. R Foundation for Statistical Computing, Vienna, Austria.URL http://www.R-project.org/.

Rettie, W. J., and Messier, F. (1998).Dynamics of woodland caribou populations at the southern limit of their range in Saskatchewan. Canadian Journal of Zoology, 76:251-259. 
Rettie, W. J., and Messier, F. (2000). Hierarchical habitat selection by woodland caribou: its relationship to limiting factors. Ecography, 23:466-478.

Schaefer, J. A., Veitch, A. M., Harrington, F. H., Brown, W. K., Theberge, J. B., and Luttich, S. N. (1999). Demography of decline of the Red Wine Mountains caribou herd. The Journal of Wildlife Management, 63:580-587.

Senft, R. L., Coughenour, M. B., Bailey, D. W., Rittenhouse, L. R., Sala, O. E., and Swift, D. M. (1987). Large herbivore foraging and ecological hierarchies. BioScience, (37):789-799.

Sims, R.A., Towill, W.D., Baldwin, K.A., and Wickware, G.M. (1997). Field guide to the forest ecosystem classification for northwestern Ontario. Forestry Canada and Ontario Ministry of Natural Resources. Thunder Bay, Ontario.

Thompson, I. D., Bakhtiari, M., Rodgers, A. R., Baker, J. A., Fryxell, J. M., and Iwachewski, E. (2012). Application of a high-resolution animal-borne remote video camera with global positioning for wildlife study: observations on the secret lives of woodland caribou. Wildlife Society Bulletin, 36:365-370.

Thompson, I. D., Wiebe, P. A., Mallon, E., Rodgers, A. R., Fryxell, J. M., Baker, J. A., and Reid, D. (2015). Factors influencing the seasonal diet selection by woodland caribou (Rangifer tarandus tarandus) in boreal forests in Ontario. Canadian Journal of Zoology, 93:87-98.

vanBeest, F. M., Van Moorter, B., and Milner, J. M. (2012). Temperature-mediated habitat use and selection by a heat-sensitive northern ungulate. Animal Behaviour, 84:723-735.

Wittmer, H. U., Sinclair, A. R., and McLellan, B. N. (2005). The role of predation in the decline and extirpation of woodland caribou. Oecologia, 144:257-267. 


\section{TABLES AND FIGURES}

Table 1. Details of video collar data collection. GPS location frequency is the rate at which locations were recorded; video intervals is the window that were recorded within; video frequency is frequency at which videos were recorded; number if videos is the total number of feeding videos that were contained within sampled forest stands.

\begin{tabular}{|c|c|c|c|c|c|c|}
\hline Caribou & Year & $\begin{array}{l}\text { Collar duration } \\
\text { in summer }\end{array}$ & $\begin{array}{c}\text { GPS } \\
\text { location } \\
\text { frequency } \\
\text { (hours) }\end{array}$ & Video intervals & Video frequency & $\begin{array}{c}\text { Number of } \\
\text { videos }\end{array}$ \\
\hline CAU243 & 2011 & Jun. 16 - Jul. 8 & 1 & $\begin{array}{c}\text { 8:00-10:30am, } \\
\text { 3:00-5:30pm }\end{array}$ & 5 minutes & 30 \\
\hline CAU247 & 2011 & Jun. 16 -Sep. 1 & 2.5 & $\begin{array}{c}8: 00-10: 15 \mathrm{am}, \\
3: 00-5: 15 \mathrm{pm}\end{array}$ & 15 minutes $^{*}$ & 55 \\
\hline CAU248 & 2011 & Jun. 16 -Sep. 4 & 2.5 & $\begin{array}{c}8: 00-10: 30 \mathrm{am}, \\
3: 00-5: 30 \mathrm{pm}\end{array}$ & 15 minutes $^{*}$ & 69 \\
\hline CAU264 & 2011 & Jun. 16 - Jul. 25 & 1 & $\begin{array}{c}\text { 8:00-10:00am, } \\
\text { 3:30-5:30pm }\end{array}$ & 5 minutes & 34 \\
\hline CAU310 & 2012 & Jun. 5 - Jun. 28 & 2.5 & $\begin{array}{c}\text { 8:00-10:30am, } \\
3: 30-5: 30 \mathrm{pm}\end{array}$ & 15 minutes & 10 \\
\hline CAU310 & 2013 & Jun. 16 - Sep. 9 & 1 & 7:00am-4:50pm & 10 minutes & 86 \\
\hline CAU312 & 2013 & Jun. 16 - Aug. 3 & 1 & 7:00am-4:50pm & 10 minutes & 99 \\
\hline
\end{tabular}

* 2 videos occur sequentially 
Table 2. V/W-type amalgamations used in the vegetation type RSF.

\begin{tabular}{|c|c|}
\hline Patch class & V/W-types \\
\hline Lowland/Bog & $\begin{array}{l}\text { V23: Tamarack (Black Spruce)/Speckled Alder/ Labrador Tea } \\
\text { V37: Black Spruce/Ericaceous Shrub/Sphagnum } \\
\text { V38: Black Spruce/Ericaceous Shrub/Sphagnum } \\
\text { W23: Open Graminoid Bog: Sedge/Sphagnum } \\
\text { W24: Open Low Shrub Bog: ericaceous shrub/Sphagnum } \\
\text { W25: Semi-Treed Bog: Black Spruce/Ericaceous } \\
\text { Shrub/Sphagnum } \\
\text { W26: Treed Bog: Black Spruce/Ericaceous Shrub/Sphagnum }\end{array}$ \\
\hline Deciduous & $\begin{array}{l}\text { V7: Trembling Aspen - Balsam Fir/Balsam Fir Shrub } \\
\text { V10: Trembling Aspen - Black Spruce - Jack Pine/Low Shrub } \\
\text { V11: Trembling Aspen - Conifer/Blueberry/ Feathermoss }\end{array}$ \\
\hline Cedar & $\begin{array}{l}\text { V21: Cedar (inc. Mixedwood)/Mountain Maple } \\
\text { V22: Cedar (inc. Mixedwood)/Speckled Alder/Sphagnum }\end{array}$ \\
\hline Balsam Fir Coniferous & $\begin{array}{l}\text { V24: White Spruce - Balsam Fir/Shrub Rich } \\
\text { V25: White Spruce - Balsam Fir/Feathermoss }\end{array}$ \\
\hline Balsam Fir Mix & $\begin{array}{l}\text { V14: Balsam Fir Mixedwood } \\
\text { V15: White Spruce Mixedwood } \\
\text { V16: Balsom Fir - White Spruce Mixedwood/Feathermoss }\end{array}$ \\
\hline Black Spruce/Jack Pine & V31: Black Spruce - Jack Pine/Tall Shrub/Feathermoss \\
\hline Coniferous & $\begin{array}{l}\text { V32: Jack Pine - Black Spruce/ericaceous Shrub/Feathermoss } \\
\text { V33: Black Spruce/Feathermoss }\end{array}$ \\
\hline Black Spruce/Jack Pine Mix & $\begin{array}{l}\text { V17: Jack Pine Mixedwood/Shrub Rich } \\
\text { V18: Jack Pine Mixedwood/Feathermoss } \\
\text { V19: Black Spruce Mixedwood/Herb Rich } \\
\text { V20: Black Spruce Mixedwood/Feathermoss }\end{array}$ \\
\hline Upland Open Understory & $\begin{array}{l}\text { V28: Jack Pine/Low Shrub } \\
\text { V29: Jack Pine/Ericaceous Shrub/Feathermoss } \\
\text { V30: Jack Pine - Black Spruce/Blueberry/Lichen }\end{array}$ \\
\hline Upland/Lowland Transition & $\begin{array}{l}\text { V34: Black Spruce/Labrador Tea/Feathermoss } \\
\text { V35: Black Spruce/Speckled Alder/Sphagnum } \\
\text { V36: Black Spruce/Bunchberry/Sphagnum (Feathermoss) }\end{array}$ \\
\hline Rich Fen & $\begin{array}{l}\text { W17: Extremely Rich Fen: Ericaceous Shrub/Sedge/Brown Moss } \\
\text { W18: Moderately Rich Fen: Tamarack-Black Spruce/Ericaceous } \\
\text { Shrub }\end{array}$ \\
\hline Poor Fen & $\begin{array}{l}\text { W19: Moderately Rich Fen: Graminoid } \\
\text { W20: Poor fen: Ericaceous Shrub/Wire Sedge/Sphagnum } \\
\text { W21: Poor Fen: Ericaceous Shrub/Sphagnum } \\
\text { W22: Poor Fen: Black Spruce-Tamarack/Ericaceous } \\
\text { Shrub/Sphagnum }\end{array}$ \\
\hline Marsh & $\begin{array}{l}\text { W10: Marsh: Mixed: Organic Substrate } \\
\text { W11: Marsh: Cattail } \\
\text { W12: Meadow Marsh: Tall Sedge } \\
\text { W13: Meadow Marsh: Bluejoint Grass }\end{array}$ \\
\hline
\end{tabular}


Table 3. Total number of bites taken for each food item that appeared in the caribou diet in the 383 feeding videos.

\begin{tabular}{lc}
\hline \multicolumn{1}{c}{ Species, genus, or } & Total number of bites \\
\multicolumn{1}{c}{ broader grouping } & \\
\hline Arboreal lichen & 749 \\
Alnus & 27 \\
Aralia nudicaulis & 105 \\
Aster & 18 \\
Chamaedaphne calyculata & 1 \\
Cladina & 2690 \\
Cladonia & 11 \\
Clintonia borealis & 208 \\
Coptis & 1 \\
Cornus canadensis & 50 \\
Cornus stolonifera & 65 \\
Cornus alternifolia & 10 \\
Diervilla lonicera & 157 \\
Equisetum & 1185 \\
Graminoids & 390 \\
Litter & 13 \\
Lycopodium & 4 \\
Maianthemum canadense & 196 \\
Maianthemum trifolium & 704 \\
Menyanthes trifoliata & 488 \\
Petasites & 2 \\
Picea mariana & 18 \\
Pleurozium & 54 \\
Populus & 49 \\
Rosa & 21 \\
Rubus & 56 \\
Salix & 25 \\
Trientalis borealis & 97 \\
Fungi & \\
Vaccinium & \\
\hline & \\
&
\end{tabular}


Table 4. Model coefficients $(\beta)$ and associated standard error and significance of plant level RSF.

\begin{tabular}{cccc}
\hline Food item & Estimate & Standard error & $\mathrm{P}$ \\
\hline Diervilla lonicera & 0.264 & 0.479 & 0.581 \\
Aralia nudicaulis & 0.0765 & 0.359 & 0.831 \\
Cladina & 0.754 & 0.180 & $2.74 \mathrm{e}^{-5} *$ \\
Clintonia borealis & 1.06 & 0.360 & $0.00326 *$ \\
Maianthemum canadense & -0.807 & 0.251 & $0.00133 *$ \\
Maianthemum trifolium & -0.676 & 0.234 & $0.00392 *$ \\
Menyanthes trifoliata & -0.472 & 0.326 & 0.148 \\
Graminoids & 0.0849 & 0.232 & 0.715 \\
Equisetum & 0.0548 & 0.205 & 0.789 \\
\hline
\end{tabular}

* $\mathrm{P}<0.05$ 
Table 5. Model coefficients ( $\beta$ ) and associated standard error and significance of vegetation type RSF.

\begin{tabular}{cccc}
\hline Patch class & Estimate & Standard error & $\mathrm{P}$ \\
\hline Intercept (Lowland/bog) & 0.160 & 0.428 & 0.708 \\
Deciduous & avoid $^{\mathrm{a}}$ & $\mathrm{NA}$ & $\mathrm{NA}$ \\
Cedar & -0.474 & 0.939 & 0.614 \\
Balsam fir coniferous & -1.95 & 0.540 & $0.000299 *$ \\
Balsam fir mix & -2.89 & 0.477 & $1.45 \mathrm{e}^{-9} *$ \\
Black spruce/jack pine coniferous & -0.3315 & 0.329 & 0.314 \\
Black spruce/jack pine mix & -2.15 & 0.429 & $5.44 \mathrm{e}^{-7} *$ \\
Upland open understory & 1.10 & 0.453 & $0.0152 *$ \\
Upland/lowland transition & -0.379 & 0.344 & 0.271 \\
Rich fen & -6.19 & 1.15 & $7.43 \mathrm{e}^{-8} *$ \\
Poor fen & -1.51 & 0.577 & $0.00865 *$ \\
Marsh & -3.76 & 1.56 & $0.0157 *$ \\
\hline
\end{tabular}

$* \mathrm{P}<0.05$

${ }^{a}$ Perfect avoidance; parameter estimate approaches infinity 
Table 6. Model coefficients ( $\beta$ ) and associated standard error and significance of stand level RSF.

\begin{tabular}{cccc}
\hline FNLC stand type & Estimate & Standard error & P \\
\hline Intercept (Treed bog) & -2.32668 & 0.16362 & $<2 \mathrm{e}-16 *$ \\
Thicket swamp & avoid $^{\mathrm{a}}$ & $\mathrm{NA}$ & $\mathrm{NA}$ \\
Open fen & avoid $^{\mathrm{a}}$ & $\mathrm{NA}$ & $\mathrm{NA}$ \\
Open bog & avoid $^{\mathrm{a}}$ & $\mathrm{NA}$ & $\mathrm{NA}$ \\
Sparse treed & avoid $^{\mathrm{a}}$ & $\mathrm{NA}$ & $\mathrm{NA}$ \\
Community/ infrastructure & avoid $^{\mathrm{a}}$ & $\mathrm{NA}$ & $\mathrm{NA}$ \\
Freshwater marsh & 1.22807 & 0.54170 & $0.023386 *$ \\
Treed fen & 0.62287 & 0.19737 & $0.001601 *$ \\
Coniferous swamp & -0.85267 & 0.24356 & $0.000464 *$ \\
Coniferous treed & -0.09823 & 0.19298 & 0.630494 \\
Mixed treed & 0.57817 & 0.21309 & $0.006662 *$ \\
Deciduous treed & 0.50752 & 0.46954 & 0.279740 \\
Sparse disturbance & -1.04061 & 0.44630 & $0.019720 *$ \\
Treed disturbance & 0.59411 & 0.25952 & $0.022064 *$ \\
\hline
\end{tabular}

* $\mathrm{P}<0.05$

${ }^{a}$ Perfect avoidance; parameter estimate approaches infinity 
Table 7. Summary of food item selection patterns across the plant, vegetation type, and stand scales. $+=$ selection, $\mathrm{o}=$ used in proportion to availability, $-=$ avoidance .

\begin{tabular}{cccc}
\hline Food item & Plant & Vegetation type & Stand \\
\hline D. lonicera & $\mathrm{o}$ & - & + \\
A. nudicaulis & $\mathrm{O}$ & - & $\mathrm{o}$ \\
Cladina & + & + & $\mathrm{O}$ \\
C. borealis & + & - & + \\
M. canadense & - & $\mathrm{o}$ & + \\
M. trifolium & - & - & + \\
M. trifoliata & $\mathrm{o}$ & - & + \\
Graminoids & $\mathrm{o}$ & $\mathrm{o}$ & + \\
Equisetum & $\mathrm{o}$ & & \\
\hline
\end{tabular}




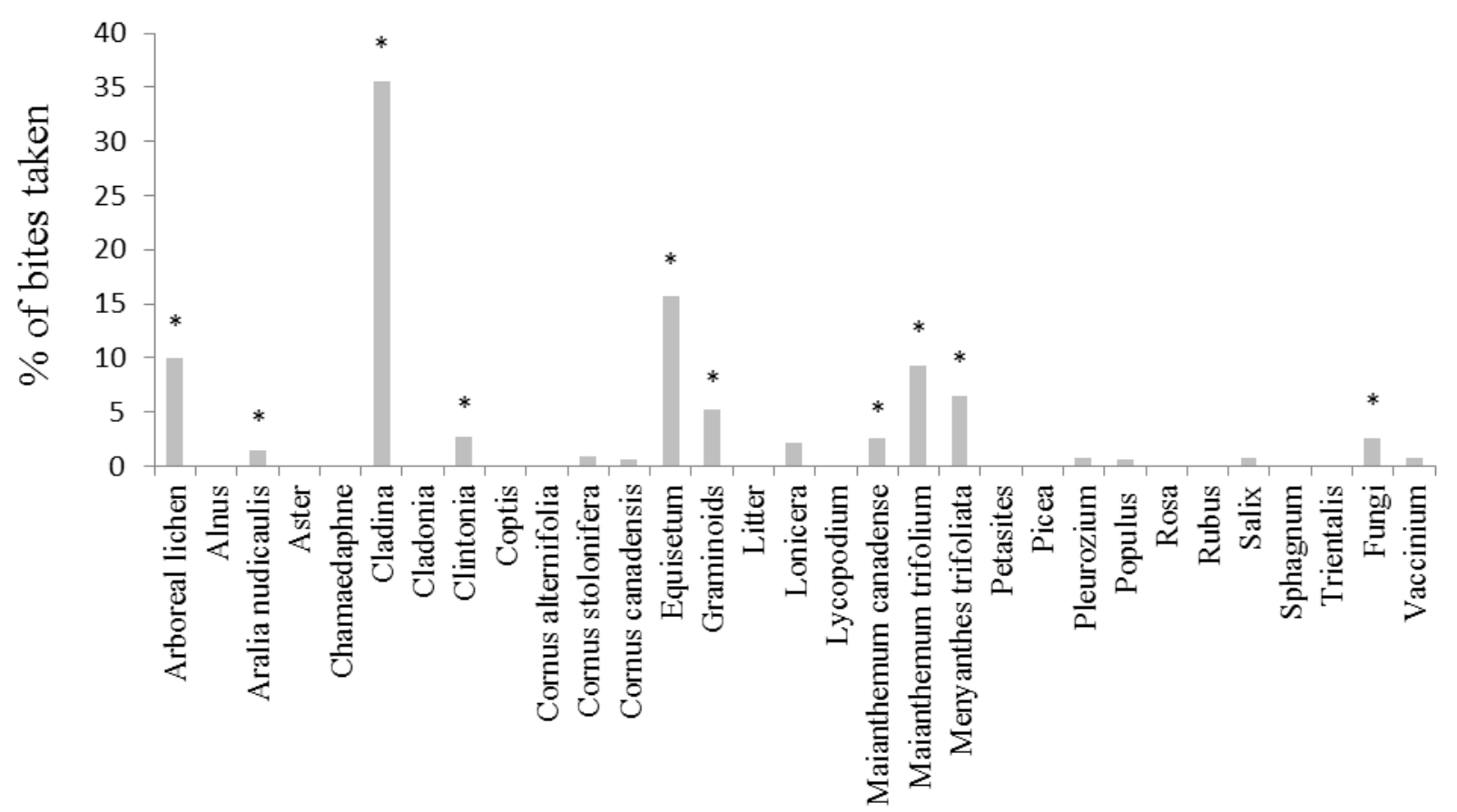

Species, genus, or broader grouping

Figure 1. Percentage of bites taken by food item from all caribou. Asterisks indicate food items representing $>1 \%$ of total bites taken. 


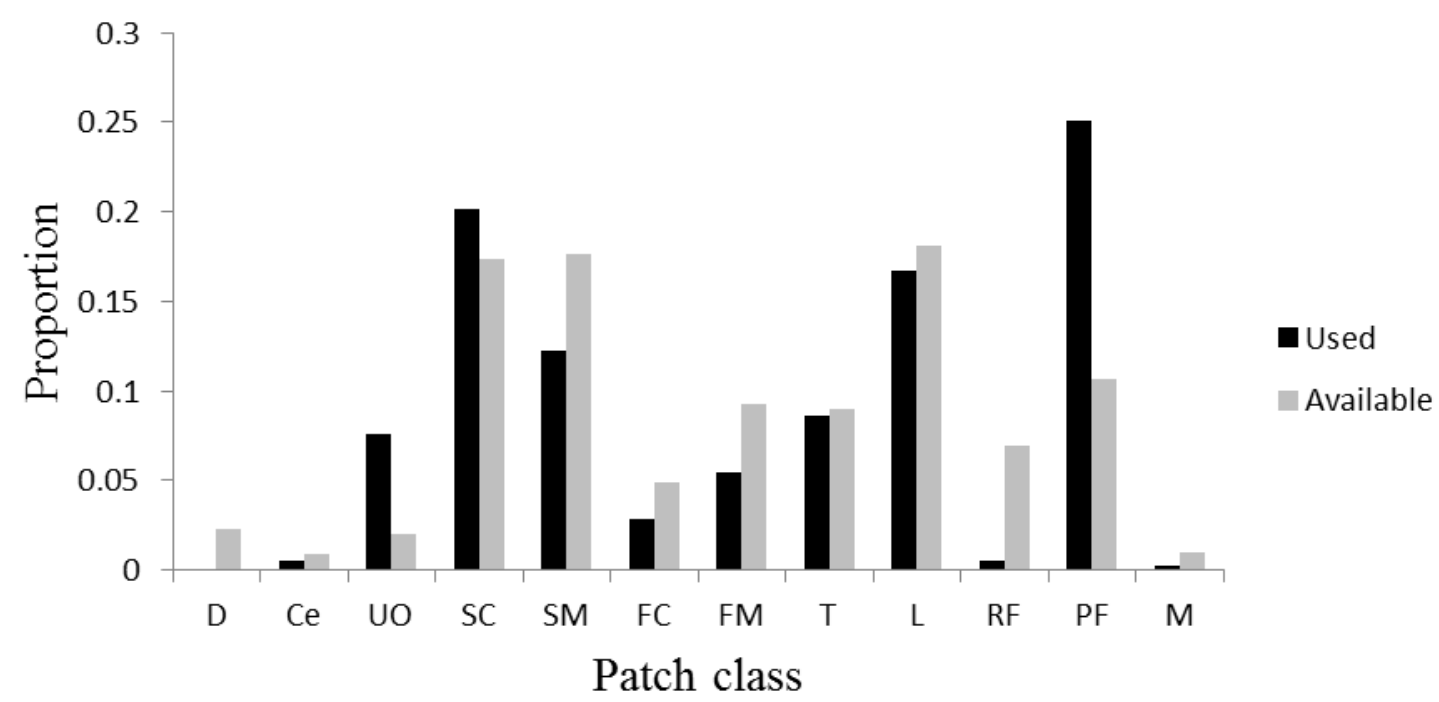

Figure 2. Relative use and relative availability of each patch class. $\mathrm{D}=$ deciduous, $\mathrm{Ce}=$ cedar, $\mathrm{UO}=$ upland open understory, $\mathrm{SC}=$ black spruce/jack pine coniferous, $\mathrm{SM}=$ black spruce/jack pine mixed, $\mathrm{FC}=$ balsam fir coniferous, $\mathrm{FM}=$ balsam fir mixed, $\mathrm{T}=$ upland/lowland transition, $\mathrm{L}=$ lowland/bog, $\mathrm{RF}=$ rich fen, $\mathrm{PF}$ - poor fen, $\mathrm{M}=$ marsh. 


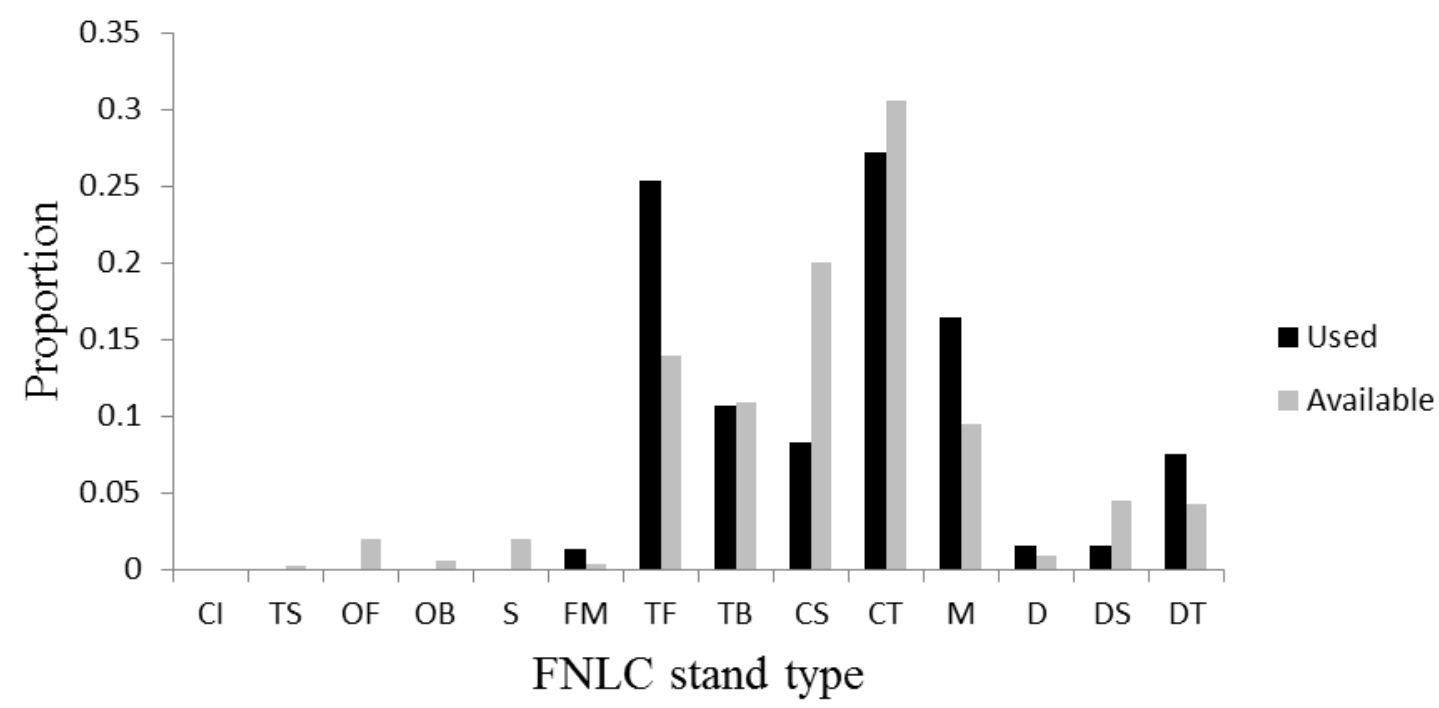

Figure 3. Relative use and relative availability of each FNLC stand type. $\mathrm{CI}=$ community/infrastructure, $\mathrm{TS}=$ thicket swamp, $\mathrm{OF}=$ open fen, $\mathrm{OB}=$ open bog, $\mathrm{S}=$ sparse treed, $\mathrm{FM}=$ freshwater marsh, $\mathrm{CS}=$ coniferous swamp, $\mathrm{TF}=$ treed fen, $\mathrm{TB}=$ treed bog, $\mathrm{D}=$ deciduous, $\mathrm{M}=$ mixed, $\mathrm{CT}=$ coniferous treed, $\mathrm{DS}=$ sparse disturbance, $\mathrm{DT}=$ treed disturbance. 
A. nudicaulis

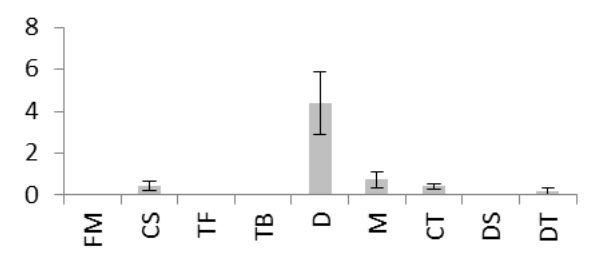

C. borealis

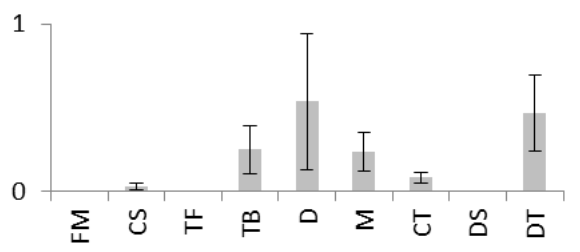

Equisetum
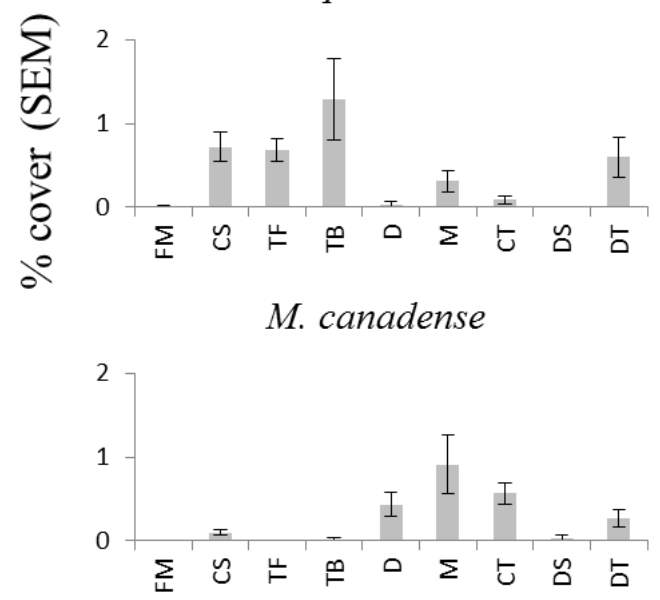

M. trifoliata

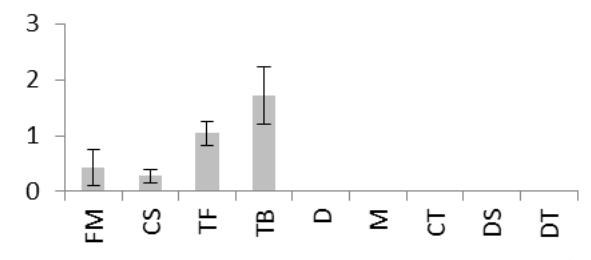

D. lonicera

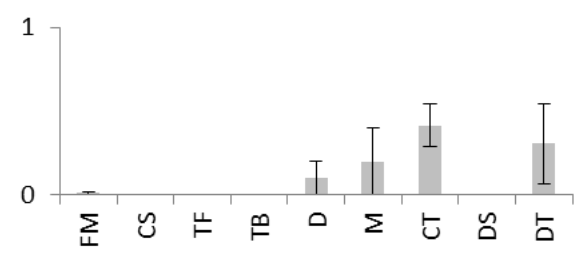

Cladina

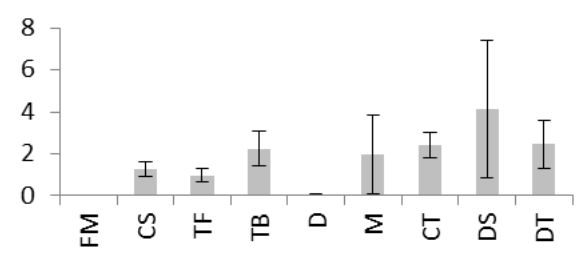

Graminoids

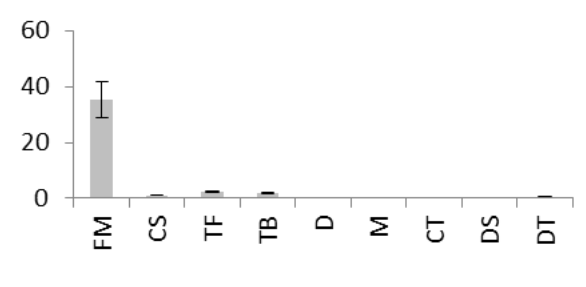

M. trifolium

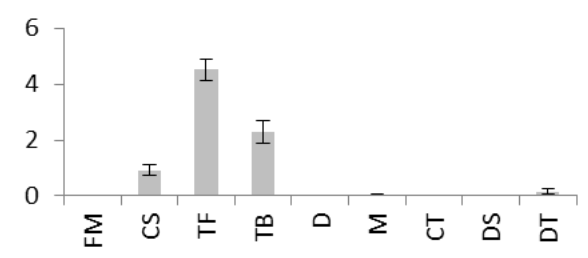

FNLC stand type

Figure 4. Percentage cover of the nine food items included in the plant RSF by FNLC stand type. Values are mean $\pm \mathrm{SEM}$. $\mathrm{FM}=$ freshwater marsh, $\mathrm{CS}=$ coniferous swamp, $\mathrm{TF}=$ treed fen, $\mathrm{TB}=$ treed bog, $\mathrm{D}=$ deciduous, $\mathrm{M}=$ mixed, $\mathrm{CT}=$ coniferous treed, $\mathrm{RD}=$ sparse disturbance, $\mathrm{OD}=$ treed disturbance. 
A. nudicaulis

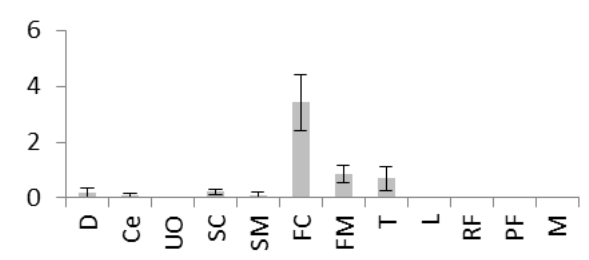

C. borealis

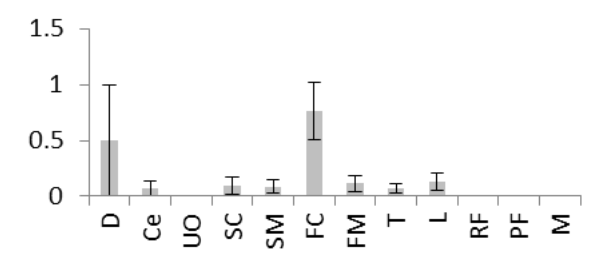

Equisetum

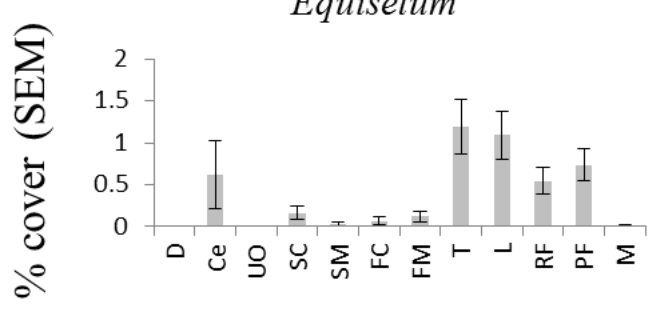

M. canadense

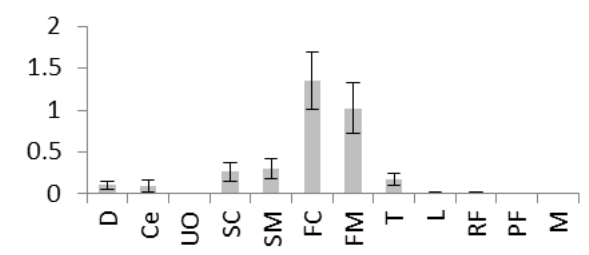

\section{M. trifoliata}

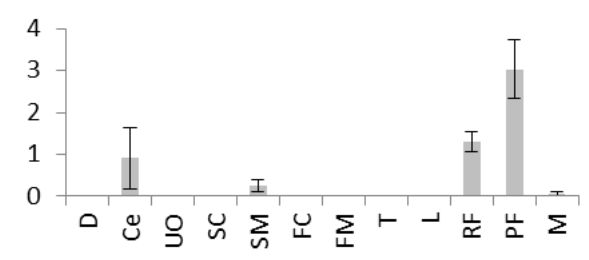

D. lonicera

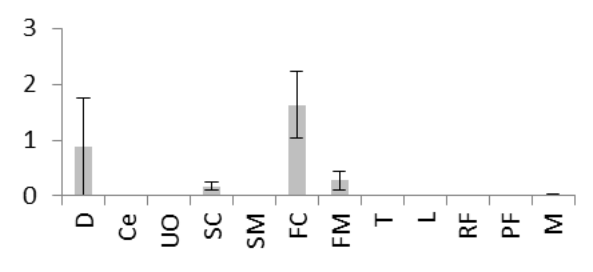

Cladina

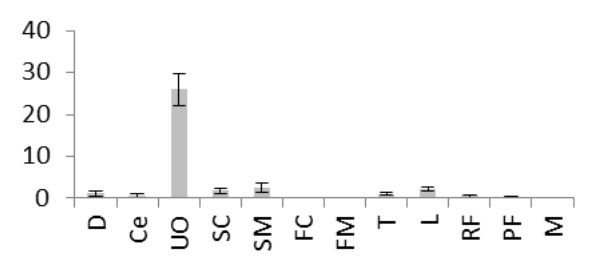

Graminoids

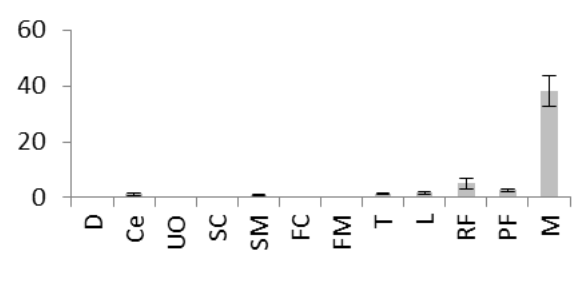

M. trifolium

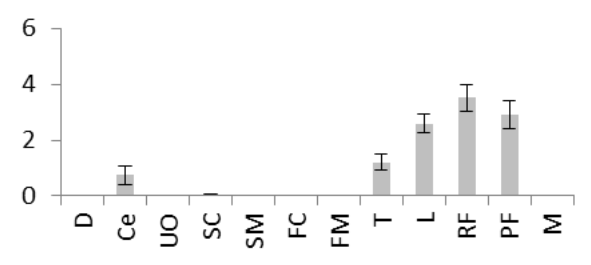

Patch class

Figure 5. Percentage cover of the nine food items included in the plant RSF by patch class. Values are mean $\pm \mathrm{SEM}$. $\mathrm{D}=$ deciduous, $\mathrm{Ce}=$ cedar, $\mathrm{UO}=$ upland open understory, $\mathrm{SC}=$ black spruce/jack pine coniferous, $\mathrm{SM}=$ black spruce/jack pine mixed, $\mathrm{FC}=$ balsam fir coniferous, $\mathrm{FM}=$ balsam fir mixed, $\mathrm{T}=$ upland/lowland transition, $\mathrm{L}=$ lowland/bog, $\mathrm{RF}=$ rich fen, $\mathrm{PF}=$ poor fen, $\mathrm{M}=\mathrm{marsh}$. 
Marsh

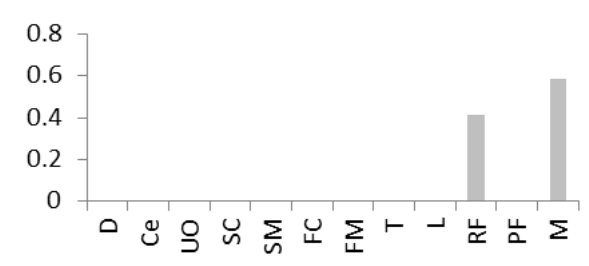

Treed bog

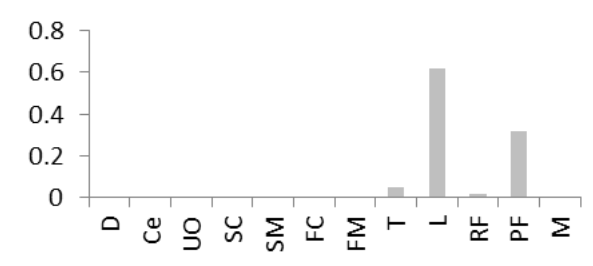

Coniferous treed

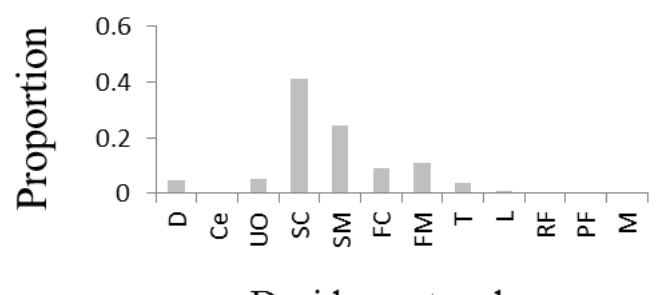

Deciduous treed

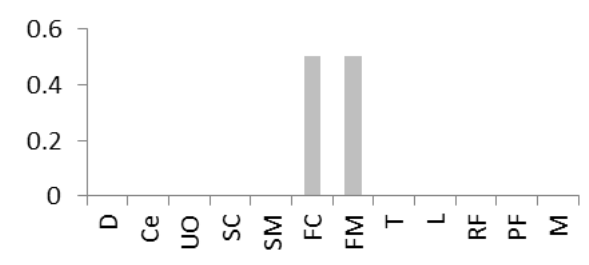

Treed disturbance

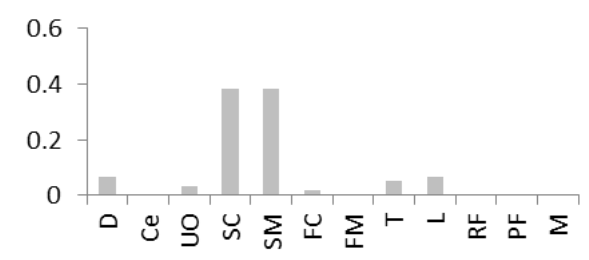

Treed fen

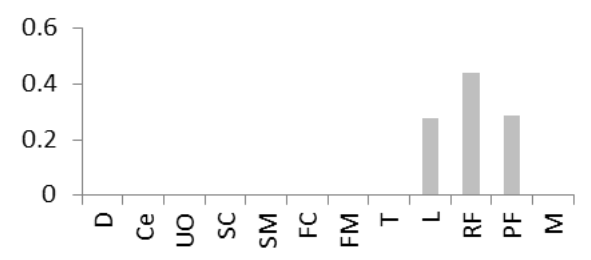

Coniferous swamp

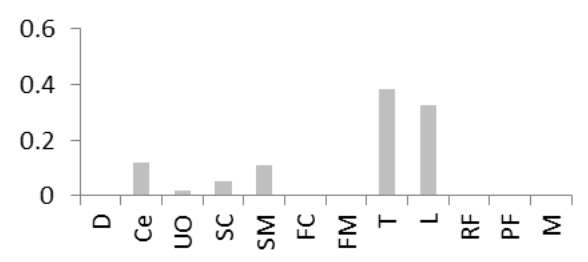

Mixed treed

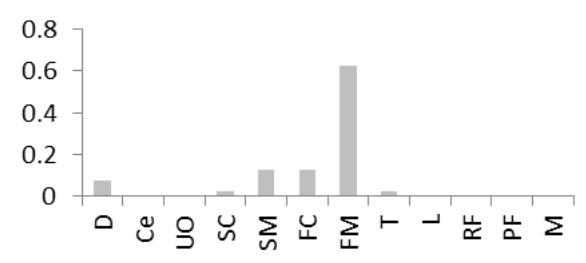

Sparse disturbance

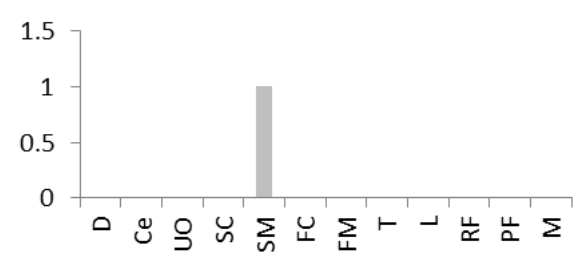

Patch class

Figure 6. FNLC stand type composition of patch classes. $\mathrm{D}=$ deciduous, $\mathrm{Ce}=$ cedar, $\mathrm{UO}=$ upland open understory, $\mathrm{SC}=$ black spruce/jack pine coniferous, $\mathrm{SM}=$ black spruce/jack pine mixed, $\mathrm{FC}=$ balsam fir coniferous, $\mathrm{FM}=$ balsam fir mixed, $\mathrm{T}=$ upland/lowland transition, $\mathrm{L}=$ lowland/bog, $\mathrm{RF}=$ rich fen, $\mathrm{PF}=$ poor fen, $\mathrm{M}=$ marsh. 